\title{
READERS
Insight
}

International Journal of Entrepreneurial Research (IJER)

ISSN:

www.readersinsight.net/jei

\section{The Effect of Training on Employees' Productivity in Public Organizations in U.A.E}

\author{
Rashid Ali Ahmed Mohamed Al Ali ${ }^{*}$, Rosman Md Yusoff ${ }^{2}$, Fadillah Binti Ismail ${ }^{3}$, Abdul Ghafoor \\ $\mathrm{Kazi}^{4}$
}

${ }^{1}$ Faculty of Technology Management and Business, Universiti Tun Hussein Onn Malaysia

${ }^{2}$ Centre for General Studies and Co-Curricular, Universiti Tun Hussein Onn Malaysia

${ }^{3}$ Faculty of Technology Management and Business, Universiti Tun Hussein Onn Malaysia

${ }^{4}$ Faculty of Management Science, Shaheed Zulfiqar Ali Bhutto Institute of Science and Technology, Hyderabad, Sindh, Pakistan

*Corresponding author: rashed_alalili@hotmail.com

\begin{abstract}
Today, many organizations of different sizes are facing challenges related to the productivity of labour and staff. Training of is an important factor that contributes positively to employee's productivity. This study is an attempt to discuss the theories of training and examines the influence of training on the productivity of employees in the General Directorate of Residency and Foreigners Affairs in U.A.E. It is assumed in this study that many organizations in U.A.E have weak interest to use new theories in training and want to continue on traditional methods which may not lead to the desired results. Therefore, the lack of effective training is one of the main reasons for low productivity in public organizations in UAE. The findings of this study showed that training is correlated with employee's productivity in a positive, causal, and high degrees of association. Therefore, it is highly recommended to focus on using suitable training methods that match the type of business and tasks required from employees in order to increase their productivity.
\end{abstract}

Keywords: Training, Employee's Productivity
ARTICLE INFORMATION

Received: 1 July 2018

Revised: 1 November 2018 Accepted: 13 November 2018

DOI:

10.31580/ijer.v1i1.135

\section{INTRODUCTION}

Training is an important factor adopted by modern organizations and directly affects the productivity of staff. Most studies in the field of development and quality showed that training has become a key part of the human resource strategies for development staff skills and knowledge in business organizations, where government agencies can only achieve high level of productivity through personnel training and providing the necessary resources for training programs (Al-Tarawneh, 2012).

The contributions of training is significant in achieving the objectives and strategies of most organizations in today business world, on the other hand, the changes that expected to happen to the productivity of the employees after training could lead more revenues and improve the service and products of the organization on the long term, so regulatory development through training is a special expansions in the business sector through in various aspects of work and this can be done by increasing individual needs to update their skills and acquire new skills through a well thought out training programs in accordance with the latest theories and scientific methods (Rawyah, 2005).

Nowadays, training is U.A.E is the most important factor to increases the efficiency and the effectiveness of both employees and the productivity of organization doing business in U.A.E. As many studies showed that the performance of employee depends on various factors. But the most important factor of employee productivity is training because practicing continues development through training which is very important to enhance the capabilities of employees as well as the productivity of public companies in U.A.E. Thus, employees who have more experience in doing their job have shown higher level of productive (Fakhar and Anwar, 2008).

\section{THE AIM OF THIS STUDY}

This study assumes that many organizations in U.A.E have weak interest to use new theories in training and want to continue on traditional methods which may not lead to the desired results, also most of the institutions in the Arab world in general and U.A.E in particular, does not evaluate the methods and means of training modern before you begin in those programs which is discussed in the current study.

Therefore, the aim of this study is to discuss the theories of training and the effect of training on the productivity of employees in the General Directorate of Residency and Foreigners Affairs in U.A.E. Thus, this study investigated the impact of training of employees working in government organizations.

\section{THE METHODOLOGY}

To measure the degree of association between training and employee's productivity, this study used a quantitative method (Sekaran, 2003). Quantitative approach is based in statistical analysis to achieve the objective of this study (Donald et al., 2002) category. Normally, quantitative approach is widely used in similar researches because this approach is very accurate in testing predefined hypotheses and correlations between variables (Given and Lisa, 2008). The primary data was collected through distribution of questionnaires 
inside General Directorate of Residency and Foreigners Affairs-Dubai (DNRD). After collecting the questionnaire form the respondents and determining the valid questionnaires for data analysis, Cronbach's alphas were calculated for all subscales of the instrument to determine its reliability before conducting analysis.

\section{THE CONCEPT OF TRAINING}

Training is the process of teaching, developing the skills and knowledge of individuals that relate to particular useful competencies. Training is a useful practice that has specific objectives of improving individuals' capability, learning ability, performance and productivity (Trevisani, 2016). The principles of training forms the central of preparations and provides the pillar of development in modern organizations (Afshan et al., 2012). Today most of organizations needs for continuous development through continuous training and maintain the skills and knowledge of employees by continues upgrading and updating them throughout working life (Sinikka, 2013).

Elham (2016) defined training as "an effort to provide the employee with the knowledge and information that he/she has to acquire the skills necessary to perform the work, develop it, enhance work knowledge and experience to increase his/her current job performance".

The core of strength for every organization mainly comes from its employees. To strength develop them, leads to a strong foundation for the success of organization in the future, thus managers have continue developing themselves and also have a commitment to their employees and develop their whole potential. Employees depend on managers and the organization depends on the whole of them in order to achieve success (Richard, 2012).

Training and development basically not only improve the employee productivity but also upgrade the organization. In other words, employee development is the main key to the organizational sustainable development. It is better for organizations to have employees with a quick ability to adjust to an ever-changing world market. Hence, companies need to invest and develop in outstanding employee training and development to preserve the employees and to be successful. The twenty one century would be appropriate to those organizations, which have the ability to learn quickly and adjust to changes than their competitors. Training boosts employees' initiative and the quality of work, herewith encouraging them to be more committed to achieve the organizational objectives and goals and in turn promoting the employees' efficiency in the organization (Maimuna and Rashad, 2013).

\section{TRAINING ISSUES IN U.AE}

In public organizations of United Arab Emirates, expertise, skills and human resources, are very crucial assets that lead and mobilize the performance and productivity. This is because the service provided by UAE public organization employees (human resource), as a service industry, strongly stand for the service. The study consequently looks up to investigate and examine the impact of training and job performance on the employees' productivity in the public organization in UAE. Moreover, to find the answer of how the dynamic and effective training simply leads to a very outstanding employee performance within the organization as well as strength and higher the productivity of organization (Elena, 2000).

According to Global Competitiveness Report for the year 20162017 for competition in productivity, it is found that UAE has taken the highest rank among other Arab countries and Gulf region as well, but U.A.E has ranked 16th globally despite the huge efforts of the government to increase the productivities of local companies and the overall performance as well. The report indicates a clear need for all to make more effort to improve the core competitiveness of local companies in U.AE through continuous development in the performance.

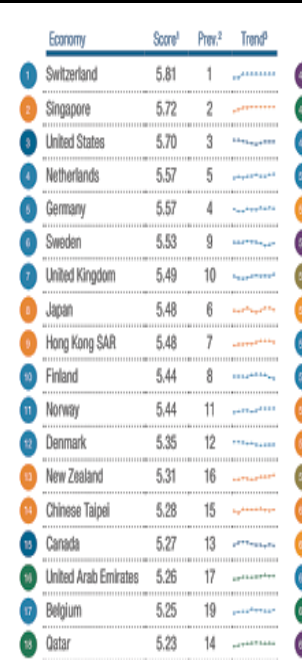

\begin{tabular}{|c|c|c|c|}
\hline Exonomy & Scout' & Prow ${ }^{2}$ & Trones \\
\hline (2) Sauth Afirica & 4,47 & 49 & "بstron \\
\hline (2) Banain & 4.47 & 3 & $-n$ \\
\hline 0 la/ia & 4.45 & 4 & 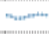 \\
\hline (2) Aligata & 4.44 & 54 & 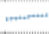 \\
\hline (1) Máto & 441 & 5 & 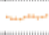 \\
\hline (2) Avanda & 4.41 & 58 & $+\cdots$ \\
\hline (2) Karahstian & 4.41 & 42 & 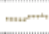 \\
\hline (1) costef fiea & 4.41 & 52 & 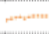 \\
\hline - Tukney & 439 & 51 & 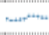 \\
\hline (2) Slueria & 439 & 59 & 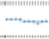 \\
\hline (2) Philipphes & 436 & 4 & nats \\
\hline 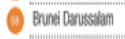 & 435 & $\mathrm{Na}$ & 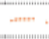 \\
\hline (2) Georga & 4.32 & 的 & ........ \\
\hline Venam & 4.31 & 56 & (n) \\
\hline Colandia & 430 & 61 & 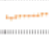 \\
\hline (2) Pomania & 430 & 53 & 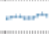 \\
\hline Jxaden & 429 & 64 & $\cdots$ \\
\hline (2) Bolswatia & 4.28 & $\pi$ & $\cdots$ \\
\hline
\end{tabular}

\begin{tabular}{|c|c|c|c|}
\hline Eemong & Soxn' & Prow: ${ }^{2}$ & $\operatorname{Tronf}^{6}$ \\
\hline (1) $\angle A O P D R$ & 3.93 & 80 & $\sqrt{n}$ \\
\hline 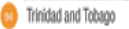 & 3.93 & 89 & (n) \\
\hline (2) Tinisla & 392 & 92 & $-\ldots$ \\
\hline (1) Kena & 3.90 & 9 & 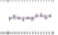 \\
\hline (1) Bhilen & 387 & 105 & $\ldots$ \\
\hline 0 Nepal & 3.87 & 100 & 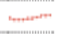 \\
\hline (2) Che oflowit & 3.86 & 91 & surs \\
\hline Mobover & 388 & 84 & 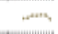 \\
\hline (2) Letermon & 3.84 & 101 & $+\infty$ \\
\hline Monpolia & 3.84 & 104 & 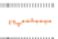 \\
\hline 1) Narasga & 381 & 100 & . \\
\hline (2) Aggentina & 3.81 & 106 & . \\
\hline Elsatrator & 381 & 95 & s.s.s.s. \\
\hline (2) Bangladesch & 3.80 & 107 & (n) \\
\hline Besnias Herengomina & 380 & 111 & 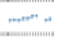 \\
\hline Cesom & 3.79 & 103 & son \\
\hline Ellikopia & 3.77 & 109 & (-1, \\
\hline (1) crepe verde & 3.76 & 112 & $\ldots$ \\
\hline
\end{tabular}

Table 1: The global competition index in productivity worldwide (Global Competitiveness Index 2016-2017 and World Economic Forum -Davos)

Reading the data in Table 1.1 shows that the development in productivity can't be achieved if there is a lack of desire to develop the performance through training, and by introducing scientific methods and modern training approaches the work of the organization and the productivity of employees will be enhanced (Global Competitiveness Index 2016-2017).

It is found that less than $50 \%$ percent of the whole companies of UAE normally have a formal process for assessing the needs of employees' training. And this compares to a figure of $80 \%$ in the UK and $85 \%$ in France, however the figure is lower in the most of other Este European countries (Holden \& Livian, 1993). Both European and UAE organizations utilize comparable ranges of methods for realizing the training needs, including training audits, analysis of business plans, performance appraisal, line management and employee requests. Sufficient, delicate and timely information on the needs of training is fundamental if organizations are to insure that the training programs they cast to their employees really contributes to achieving their business goals and objectives. Less than 40 percent of organizations in UAE register the plan of the employees' personal training and development in writing. Only $35 \%$ obtain a formal staff appraisal system that is actually implemented very well, whereas $19 \%$ only acknowledge of having a system of staff appraisal, which, practically, is only implemented variably. Productivity of employees' evaluation is as significant as the individual training events evaluation, and jointly they could be used to back up the concept of a learning organization that makes a great effort to achieve excellence (Stephen, 2001).

Based on above arguments, $t$ is evident that the practices of training and development in the UAE's will increase the business and commerce organizations and that the outcomes could provide a starting for additional training development plans in the UAE or for comparative works.

\section{EMPLOYEE PRODUCTIVITY}

Today, the organization members want to be engaged in the organization management, rather than to be a usual employee. Participation in management is very important and essential for the motivating employees for work (McConnell, 2005).

According to Uğur (2003), the productivity of employee is matter that should be overstressed by the enterprises management of, due to that low workforce effectively is an index of other inputs such as technology and capital, which, therefore, leads to the reducing the total factor productivity. This indicates that workforce productivity is the core and engine of all other results of productivity.

As was defined in Oxford dictionary (2007), productivity is the efficiency with which things are being produced. Employee productivity yet is the measure of output per unit of input economically. It is the log of net sales over total employees (Rohan and Madhumita, 
2012). Hence, employee productivity of an economy as whole or industry could be determined.

In the whole organizations, the productivity of employee generally depends on encouraging and motivating the employees for achieving the organizational goals and objectives. In addition, it is known well that factors such as discipline practices and work environment factors also influence the workforce productivity.

Regardless the difficulties caused by the complexities of the office work, people have attempted to provide generic and common measures that can be used to measure the productivity of different jobs. One possibility is the use of economic measures (e.g. ratio of revenue to expenditure. However, such measures are inappropriate here, for several reasons:

- It may be argued that it is actually measuring profitability rather than productivity.

- Such these measures are strongly affected by external factors, such as the marketplace. As confounding variables, such factors could make it near impossible to identify effects of the built environment on people's productivity.

- As a public service, much of what the government undertakes does not make money.

\section{THE RELATIONSHIP BETWEEN TRAINING AND EMPLOYEE'S PRODUCTIVITY}

A simple linear regression is conducted to test the association between training and employee's productivity. As shown in Figure 1.

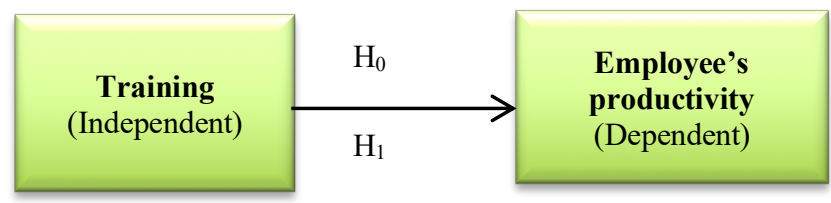

Figure 1: Regression Model between Training and Employee's productivity

The data in model summary table 2 indicates that are shown in the three outputs tables training is strongly associated with employee's productivity because $\mathrm{R}$ (correlation coefficient $=0.513$ ). Additionally, $\mathrm{R} 2=0.263$, it means that training explains $26.30 \%$ of the variation in employee's productivity. This value is considered acceptable from statistical perspective. The remaining percentage of explanation which is equal to 73.70 is due to other variables not related this study.

Table 2: simple linear regression output between training and employee's productivity.

\begin{tabular}{lllll}
\hline Model & $\mathbf{R}$ & $\mathbf{R}$ Square & $\begin{array}{l}\text { Adjusted } \mathbf{R} \\
\text { Square }\end{array}$ & $\begin{array}{l}\text { Std. Error of the } \\
\text { Estimate }\end{array}$ \\
\hline 1 & $.513^{\mathrm{a}}$ & .263 & .261 & .41326 \\
\hline a. Predictors: (Constant), Training & &
\end{tabular}

ANOVA analysis is used to examine the regression model is significant, thus the relationship between training and employee's productivity does exist. Table 3 reports that the value of $\mathrm{F}$ is high $=$ 137.533 , this value is equal to the statistical ratio of two mean square values of training and employee's productivity (i.e., training predicts the dependent variable). F value is also at the significance level ( $\rho \leq$ 0.05 ). Thus, a causal relationship does exist between training and employee's productivity.

\begin{tabular}{lllllll}
\multicolumn{2}{l}{ Table 3: ANOVA output between training and employee's productivity } \\
\hline \multicolumn{2}{l}{ Model } & $\begin{array}{l}\text { Sum of } \\
\text { Squares }\end{array}$ & df & $\begin{array}{l}\text { Mean } \\
\text { Square }\end{array}$ & F & Sig. \\
\hline \multirow{2}{*}{$1 \quad$ Regression } & 23.489 & 1 & 23.489 & 137.533 & $.000^{\mathrm{b}}$ \\
& Residual & 65.753 & 385 & .171 & & \\
& Total & 89.242 & 386 & & & \\
\hline
\end{tabular}

The table of coefficients is very important to precisely identify the effect of training on employee's productivity. Table 4 . Indicates that $B$
(Unstandardized Coefficients) $=0.406$, and B is significant $(\rho=0.000$, $\rho \leq 0.05)$. Therefore, employee's productivity is strongly predicted by training is a direct causal regression relationship. The following equation of regression explain how this hypothesis is true:

$\mathrm{Y}_{(\text {dependent variable })}=$ Constant $+\mathrm{B} * \mathrm{X}_{\text {(independent variable) }}+$ error (Std. Error) Employee's productivity $=1.980+0.406 *$ Training +0.119

Table Error! No text of specified style in document.41: Coefficients of Regression Between Training and Employee's productivity

\begin{tabular}{|c|c|c|c|c|c|}
\hline \multirow[t]{2}{*}{ Model } & \multicolumn{2}{|c|}{$\begin{array}{l}\text { Unstandardized } \\
\text { Coefficients }\end{array}$} & $\begin{array}{l}\text { Standardized } \\
\text { Coefficients }\end{array}$ & \multirow[t]{2}{*}{$\mathbf{t}$} & \multirow[t]{2}{*}{ Sig. } \\
\hline & B & Std. Er & Beta & & \\
\hline (Constant) & 1.980 & .119 & & 16.577 & .000 \\
\hline $1 \quad$ Training & .406 & .035 & .513 & 11.727 & .000 \\
\hline
\end{tabular}

a. Dependent Variable: Productivity

The conclusion from analysis showed that training is correlated with employee's productivity in a positive, causal, and high association.

\section{CONCLUSION.}

The findings of this study showed that training is a continuous effort that improves the skills, knowledge, and performance of individuals where productivity of employees are significantly enhanced after training, Thus training helps employees to carry out their work and develop their abilities in doing their work precisely and to perform their tasks properly which is reflected on the organizational performance. The productivity of employee generally depends on encouraging and motivating the employees for achieving the organizational goals and objectives. In addition, it is known well that factors such as training influence the workforce productivity. Therefore, this study examined this relationship and found that employee's productivity is highly affected by training in a positive, causal, and high degree of association. It is recommended to focus on using suitable training methods that match the type of business and tasks required from employees in order to increase their productivity.

\section{References}

Afshan Sultana. Sobia Iru. Kamran Ahme 'Nasir Mehmood. 2012. Impact of Training on Employee Performance: A Study of Telecommunication Sector in Pakistan

Al-Tarawneh, Tahseen Ahmed. 2012. commitment to apply and impact of training stages in the areas of performance of employees. Arab Journal of Security Studies and Training. 26(5)

Donald Ary, Lucy Cheser Jacobs, Asghar Razavieh. 2002. Introduction to research in education. Wadsworth, Thomson Learning.

Elena, P. A. 2000. Employee development through self-development in three retail banks. Journal of Personnel Review, 29(4), 491-508.

Elham Mobarak Hassan, K Varshosaz. 2016.The Assessment of the Efficiency of Classical and co-Operative Training in Promoting The Participation of Employees of R. PC in the Field of HSE. European Journal of Sustainable Development 5 (4), 151-166.

Fakhar Ul Afaq, Anwar Khan. 2008. Case of Pearl Continental hotels in Pakistan, Relationship of training with Employees' Performance in Hoteling Industry.

Holden, L. and Livian, Y. 1993. Does Strategic Training Policy Exist? SomeEvidence from Ten European Countries', in Hegewisch, A. and Brewster, C.(eds), European Developments in Human resource Management. London:Kogan Page.

Maimuna Muhammad Nda , Rashad Yazdani Fard. 2013. The impact of employee training and development on employee productivity.Limkokwing University of Creative Technology. Cyberjaya, Malaysia

McConnell, Charles R. 2005. Motivating Your Employees and Yourself", The Health Care Manager, 24(3), pp.284-292

Rawyah Hassan, 2005, strategic entrance to the planning and development of human resources. University House. Amman. Jordan.

Richard Chang Associates. 2012. Measuring the impact of traning, demonstrate the measureable results and return on investment. Oxford Publishing. UK

Rohan Singh, Madhumita Mohanty. 2012. Impact of Training Practices on Employee Productivity: A Comparative Study. Interscience Management Review (IMR), 2(2), pp2231-1513 
Sekaran, U. 2003. Research Methods for Business: A Skill-Building Approach. 4th Edition, John Wiley \& Sons, New York.

Sinikka Vanhala 'Sara Lindstrom. 2013. Performance in local government

HRM: the role of external customers. Department of Management and International Business 'Aalto University School of Business 'Helsinki ، Finland ‘8(3), Emerald Group Publishing Limited.

Trevisani, D. 2016. Communication for Leadership: Coaching Leadership Skills. Medialab Research, Ferrara

Uğur, Adem (2003), Productivity in Business, Sakarya Bookstore, Sakarya.

Wizner, Stephen. 2001. Beyond Skills Training. Faculty Scholarship Series. 1844 